\title{
BENTUK PENYAJIAN TARI ATU BELAH PADA MASYARAKAT GAYO KABUPATEN ACEH TENGAH
}

\author{
ELVI RIZKI ANANDA \\ Prodi Pendidikan Tari
}

\begin{abstract}
This research is the study of the form of presentation of dance parties, Or on community Gayo in Aceh Tengah. The purpose of this study was to describe the form of the presentation of dance parties, Or on community Gayo in Aceh Tengah.

In this discussion the researchers use theories related to research topics such as the sense of dance parties, Or, the theory of form and presentation of the theory.

The methods used to discuss the form of the presentation of dance parties, Or on communities of Central Aceh Gayo is a descriptive analysis method. This research population and at the same time be a sample that is custom figures, artists, and dancers. Data collection techniques include the study of librarianship, interview, observation, and documentation. Data analysis techniques using qualitative deskriftif.

Based on research is a dance which depicts a convoluted story of Atu grief of a mother. This dance was created in 1956 by Ibrahim Kadir. Examine the form presentation at dance parties, Atu would discuss all elements include motion consists of three parts, namely persalamen (opener), stages comprising the content of the motion of the lompong fly (flying locust), nuet lompong (taking the locusts), nero manganese (ask for a meal), lompong fly (flying locust), ulak mungaro (home to hunt), the benges (angry), Ilapahe (cut), mupancur rayoh (the blood gushed out), gunah (sad), mongot sebuku (crying), nunung jematue (follow the mother) beloh, musangka (ran away), wet tedoh weh (stop taking water), beloh nyerah lives (go submit lives), restless, mujadi atu (stones), and penutupen (cover). The accompaniment is poetry. Clothing worn in men's clothing namely filigree motif while the female dancers use the kebaya. Property that is used like a machete. Makeup used makeup. The theme of the dance is a dramatic dance parties, Or where the dance contains the story and the message conveyed. The pattern of the floor which is used there are eighteen floor patterns. The stage was used in dance Or Side often appears on stages using just a simple lamp.
\end{abstract}

Keywords: Dance Or spilling a form of presentation. 


\section{PENDAHULUAN}

Provinsi Aceh adalah sebuah daerah yang terletak di pulau Sumatera yang merupakan provinsi paling Barat di Indonesia. Masyarakat di Provinsi Aceh, dilihat dari letak geografisnya terbagi kedalam dua kelompok, yakni masyarakat pesisir dan masyarakat pegunungan ataupun pedalaman. Salah satu daerah yang termasuk kedalam masyarakat pegunungan adalah masyarakat Gayo yang berada di Aceh Tengah, Aceh Tenggara, Bener Meriah dan Gayo Lues. Daerah Gayo umumnya merupakan kawasan yang sangat kaya akan kebudayaan. Menurut E.B. Taylor dalam Soekanto

"kebudayaan adalah kompleks yang mencakup pengetahuan, kepercayaan, kesenian, moral, hukum, adat-istiadat dan kemampuan-kemampuan serta kebiasaan-kebiasaan yang didapat oleh manusia sebagai anggota masyarakat". Berdasarkan pengertian tersebut, dapat diketahui bahwa kebudayaan menjadi ciri dan identitas sehingga mampu mempererat ikatan solidaritas suatu masyarakat.

Kebudayaan juga berfungsi menentukan norma untuk berperilaku yang teratur serta meneruskan adat dan nilai-nilai kebudayaan. Sama halnya dengan masyarakat lainnya, masyarakat Gayo juga memiliki kebudayaan yang dapat menentukan norma dan nilai-nilai yang menjadi kebiasaan masyarakat Gayo dalam pola hidup dan bertingkah laku yang diwujudkan dalam berbagai aspek kehidupan salah satunya adalah dalam berkesenian. Selain tari, masyarakat Gayo memiliki beberapa jenis berkesenian lain, seperti sastra lisan yang terbagi kedalam kekeberen (donggeng), melengkan (kiasan/pantun), pepongoten/sebuku (tangisan/ratapan), saer (syair), kekitiken (teka-teki), dan peribahasa.

Kekeberen adalah seni sastra lisan yang disampaikan oleh orang yang lebih tua kepada yang lebih muda misalnya nenek kepada cucunya, ibu kepada anaknya, bibik kepada untilnya (keponakannya) dan lain-lain yang berisi pesan-pesan moral serta nasihat-nasihat. 
Kekeberen yang terdapat pada masyarakat Gayo adalah Atu Belah, Inen Mayak Pukes, Peteri Ijo, Peteri Bensu, Gajah Putih dan lain sebagainya. Atu Belah adalah cerita rakyat yang sampai sekarang masih diakui kebenarannya oleh masyarakat Gayo bahkan tempat peninggalannya dijadikan sebagai salah satu objek pariwisata oleh pemerintah setempat tepatnya di desa Penarun Kecamatan Linge sampai sekarang masih tetap ramai dikunjungi baik oleh penduduk setempat maupun pendatang dari luar daerah Gayo. Berdasarkarn nilai-nilai moral dan nasihat yang yang terdapat pada kekeberen tersebut para seniman-seniman gayo terinspirasi untuk menciptakan satu bentuk kesenian berupa tari yaitu tari Atu Belah agar nilai-nilai moral dan nasihat pada kekeberen tersebut tetap menjadi media pendidikan bagi generasi-generasi muda yang wujudnya dapat dilihat melalui tari ini.

Tari Atu belah berasal dari dua kata yaitu Atu (Batu) belah (membuka) jadi, Atu Belah merupakan batu yang membuka seperti dalam keadaan terbelah dua, Atu Belah berawal dari kehidupan seseorang yang berada di desa di Kabupaten Aceh Tengah dimana keluarga tersebut terdiri dari ibu, ayah, dua anaknya, satu laki-laki dan satu perempuan. Keluarga tersebut yang faktor ekonominya serba kekurangan, ibunya adalah seorang buruh tani, ayahnya hanya seorang pemburu binatang, suatu hari anaknya meminta makan kepada ibunya harus dengan memakai lauk dan ibunya merasa sedih karena ibunya berfikir bagaimana mau memberikan anaknya lauk sedangakan ibunya tidak mempunyai uang, kemudian ibunya teringat ada belalang di lumbung dan menyuruh anak perempuannya mengambil belalang tersebut dan si anak lupa menutup lumbung tersebut akhirnya belalang yang ada di lumbung semua berterbangan, setelah ayahnya pulang berburu dan ayahnya melihat belalang yang di lumbung sudah tidak ada lagi, kemudian ayahnya tersebut sangat marah kepada istrinya karena sakit hatinya melihat belalang sudah berterbangan. Padahal ayahnya mencari belalang dengan jerih payah 
dan kemudian ayahnya mengambil parang dan membelah payudara di bagian kanan istrinya, kemudian istrinya lari menuju Atu Belah. Setelah sampai disana istrinya melantunkan syair sampai berderai air mata dan akhirnya batu membuka dan istrinya masuk ke dalam batu tersebut.

Tari Atu Belah ini diciptakan oleh Ibrahim Kadir, tari Atu Belah ini dijadikan sebagai hiburan, tari Atu belah hadir di tengah masyarakat Aceh Tengah pada tahun 1956 yaitu pada acara PKA (Pekan Kebudayaan Aceh) selain di Aceh juga pernah ditampilkan dikota Bandung (1968), dikota Jakarta(1980), hingga sampai sekarang sering ditampilkan pada saat pertunjukan. Tari Atu Belah biasanya di tarikan oleh dua orang laki-laki dan tujuh orang wanita (wawancara 23 Mei 2015). Musik iringan adalah tari Atu Belah pada awalnya menggunakan alat musik tradisional seperti Gegedem (rebana) Suling, Teganing. Tetapi perkembangan zaman musik iringan tari ini juga mulai berubah dengan menambahkan alat musik seperti keyboard dan gitar. Tetapi masih ada juga yang tetap memakai alat musik tradisional dan memadukan dengan alat musik modern.

Musik iringan pada Atu Belah selain dimainkan dengan menggunakan musik pengiring yang diiringi mulai dari awal penari masuk sampai tarian itu selesai, tetapi juga menggunakan syair lagu yang dilantunkan bersamaan dengan musik yang dimainkan. Syair lagu pada tarian ini sesuai dengan gerakan yang ditarikan serta sesuai dengan gambaran atau suasana hati tari itu sendiri. Setiap bait syair lagu pada tari ini memiliki makna dan hubungan pada setiap ragam-ragam geraknya. Syair dalam tarian ini juga dijadikan sebagai pembeda antara ragam satu dengan ragam yang lainnya. Properti yang digunakan dalam tarian tersebut menggunakan parang. Busana yang dipakai pada tari Atu Belah penari laki-laki menggunakan baju adat gayo, masyarakat Gayo biasa menyebutnya dengan baju kerawang karena memiliki ciri khas warna dan motif kerawang, sedangkan penari wanita menggunakan pakaian kebaya zaman, kain sarung, kain panjang 
dan ketawak (tali pinggang) yang bermotif kerawang. Dalam penyajian tari Atu Belah terdapat yaitu pembuka, isi dan penutup. Tahapan pembuka ada satu ragam gerak, tahap kedua mempunyai dua puluh ragam gerak dan penutup mempunyai satu ragam gerak.

Berdasarkan tulisan di atas untuk menjelaskan secara lebih rinci tentang karya Atu Belah penulis memilih topik Bentuk Penyajian Tari Atu Belah dalam bentuk karya ilmiah.

\section{Landasan Teori}

Untuk membahas bentuk penyajian tari Atu Belah penulis menggunakan teori bentuk dari Hermin dan Jazuli.

\section{Lokasi dan Waktu Penelitian}

Tempat dilaksanakannya penelitian adalah di Kecamatan Bebesen kabupaten Aceh Tengah.

\section{Teknik Analisis Data}

$$
\begin{aligned}
& \text { Penulis menganalisa dan } \\
& \text { menguaraikan data-data tersebut } \\
& \text { dengan menggunkan tehnik deskriftif } \\
& \text { kualitatif yang bersifat analisis secara } \\
& \text { sistematis dengan teknik deskriptif }
\end{aligned}
$$

kualitatif yang bersifat analisis secara rinci, sehingga hasilnya dapat dilihat dalam suatu bentuk laporan ilmiah atau skripsi. Waktu yang digunakan dalam penelitian ini untuk mendapatkan data yang dibutuhkan adalah selama tiga bulan yang dilaksanakan pada Oktober 2015 sampai Desember 2015.

\section{Populasi dan Sampel}

Populasi dalam penelitian ini seniman, penari Gayo yang mengetahui tari Atu Belah, tari Atu Belah dan masyarakat Gayo Aceh Tengah.

\section{Sampel}

Sampel dalam penelitian ini adalah tokoh adat, beberapa seniman terkait, penari Gayo yang mengetahui tari Atu Belah.

\section{Tehnik Pengumpulan Data}

Tehnik pengumpulan data yang dilakukan adalah sebagai berikut:

1. Studi kepustakaan

2. Observasi

3. Wawancara

4. Dokumentasi 
ISI

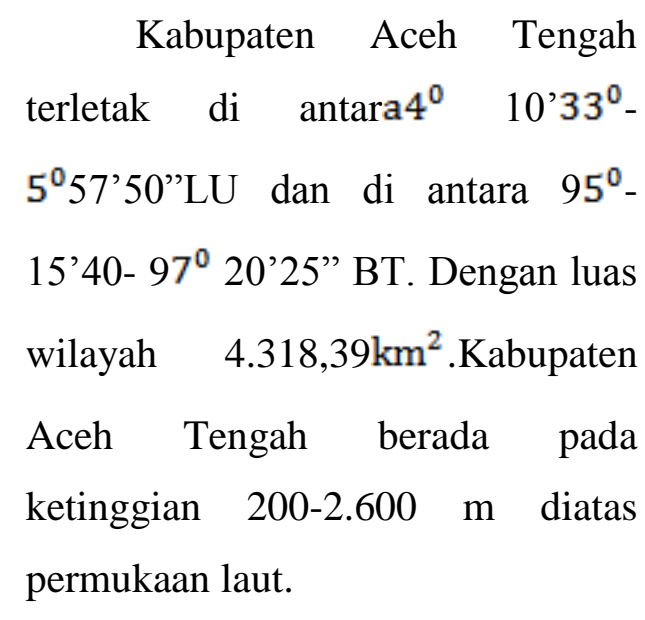

Berdasarkan letaknya, wilayah Kabupaten Aceh Tengah berada di tengah wilayah provinsi Aceh, dalam lingkup dataran tinggi Gayo dikelilingi oleh Kabupaten lainnya.Dengan demikian Kabupaten ini memiliki batas wilayah laut sebagaimana yang dimiliki oleh kabupaten lainnya di Provinsi Aceh seperti Kabupaten Aceh Selatan,Kabupaten Aceh Barat, Kabupaten Aceh singkil, Kabupaten Aceh Barat Daya, sebagian Kabupaten Aceh Besar yang memiliki wilayah garis pantai bagian barat, sedangkan garis pantai sebelah timur dimiliki oleh Kabupaten Pidie, dan sebagian Wilayah Kabupaten Aceh Besar.

Wilayah Kabupaten Aceh tengah sebagian Besar terdiri dari dataran tinggi (1.205 Meter) sehingga untuk menuju Kabupaten Aceh Tengah harus melalui daerah pengunungan/perbukitan. Wilayah yang menjadi bagian dari Kabupaten Aceh Tengah terdiri dari 14 kecamatan dan 268 desa/kelurahan paling luas yaitu Kecamatan Linge yang luasnya hampir setengah dari luas Kabupaten Aceh Tengah.

\section{Bentuk Penyajian Tari Atu Belah}

Tari Atu belah berasal dari dua kata yaitu Atu (Batu) belah (membuka) jadi, Atu Belah merupakan batu yang membuka seperti dalam keadaan terbelah dua, Atu Belah berawal dari kehidupan seseorang yang berada di desa di Kabupaten Aceh Tengah dimana keluarga tersebut terdiri dari ibu, ayah, dua anaknya, satu laki-laki dan satu perempuan. Keluarga tersebut yang faktor ekonominya serba kekurangan, ibunya adalah seorang buruh tani, ayahnya hanya seorang pemburu binatang, suatu hari anaknya meminta makan kepada ibunya harus dengan memakai lauk dan ibunya merasa sedih karena ibunya berfikir bagaimana mau memberikan anaknya lauk 
sedangakan ibunya tidak mempunyai uang, kemudian ibunya teringat ada belalang di lumbung dan menyuruh anak perempuannya mengambil belalang tersebut dan si anak lupa menutup lumbung tersebut akhirnya belalang yang ada di lumbung semua berterbangan, setelah ayahnya pulang berburu dan ayahnya melihat belalang yang di lumbung sudah tidak ada lagi, kemudian ayahnya tersebut sangat marah kepada istrinya karena sakit hatinya melihat belalang sudah berterbangan. Padahal ayahnya mencari belalang dengan jerih payah dan kemudian ayahnya mengambil parang dan membelah payudara di bagian kanan istrinya, kemudian istrinya lari menuju Atu Belah. Setelah sampai disana istrinya melantunkan syair sampai berderai air mata dan akhirnya batu membuka dan istrinya masuk ke dalam batu tersebut.

Tari Atu Belah ini diciptakan oleh Ibrahim Kadir, tari Atu Belah ini dijadikan sebagai hiburan, tari Atu belah hadir di tengah masyarakat Aceh Tengah pada tahun 1956 yaitu pada acara PKA (Pekan Kebudayaan Aceh) selain di Aceh juga pernah ditampilkan dikota Bandung (1968), dikota Jakarta(1980), hingga sampai sekarang sering ditampilkan pada saat pertunjukan.

Adapun ragam gerak tari Atu Belah yaitu persalamen (pembuka), tahapan isi terdiri dari gerak lompong terbang (belalang terbang), nuet lompong (mengambil belalang), nero mangan (minta makan), lompong terbang (belalang terbang), ulak mungaro (pulang memburu), benges (marah), Ilapahe (memotong), mupancur rayoh (bercucuran darah), gunah (sedih), mongot sebuku (menangis), nunung jematue (mengikuti ibu), beloh musangka (pergi berlari), tedoh wet weh (berhenti mengambil air), beloh nyerah nyawa (pergi menyerahkan nyawa), gelisah, mujadi atu (menjadi batu), dan penutupen (penutup).

Ragam gerak tari Atu Belah :

1. Persemahen (persembahan)

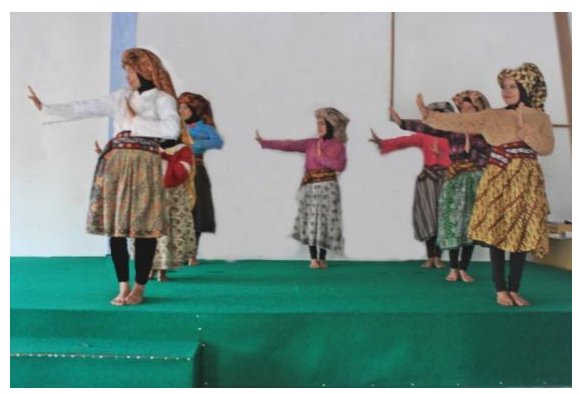


Gesture

2. Ragam Gerak

Lompong Terbang

(belalang terbang)

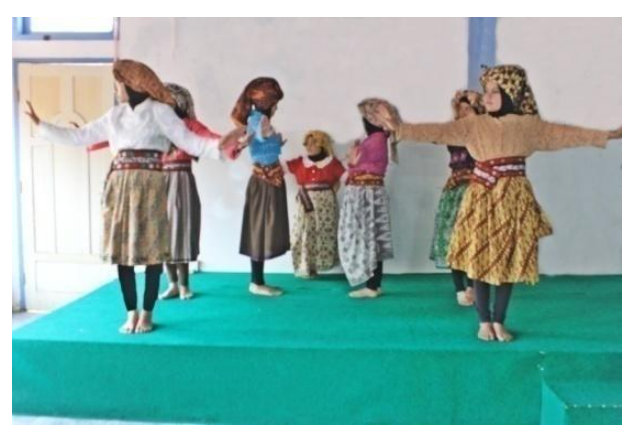

3. Ragam gerak nuet lompong (mengambil belalang)

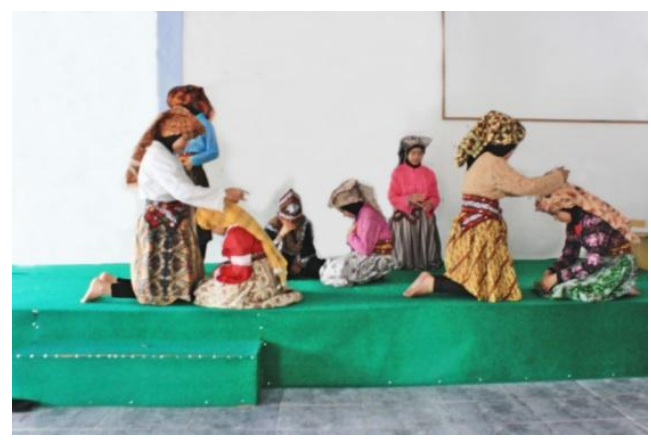

4. Ragam gerak Nero mangan (minta makan)

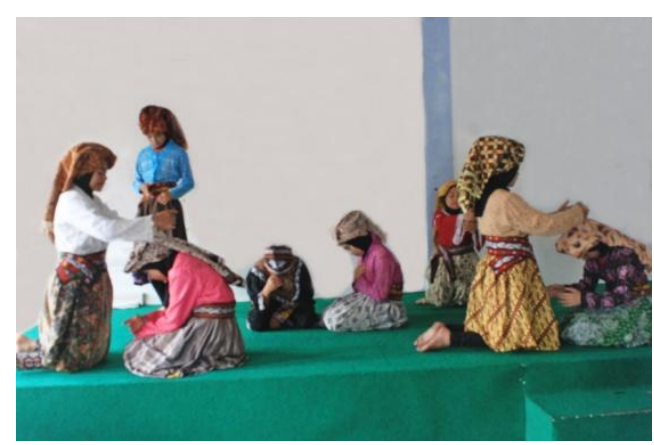

5. Ragam gerak lompong terbang ( belalang terbang)

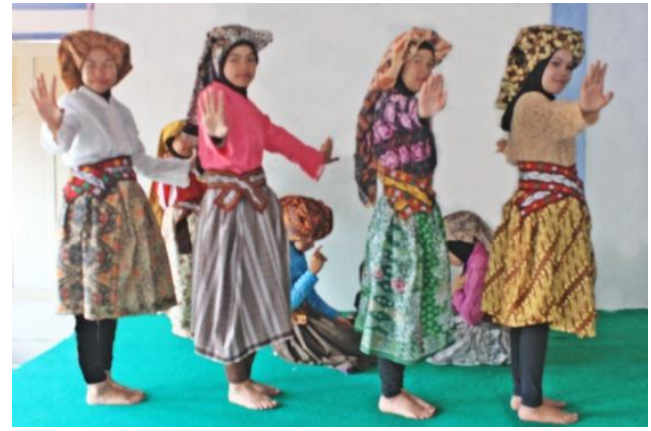

6. Ragam gerak Ulak mungaro (pulang memburu)

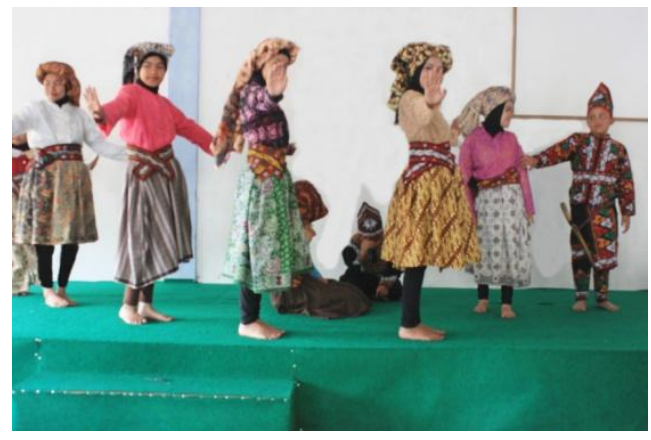

7. Ragam gerak Benges (marah)

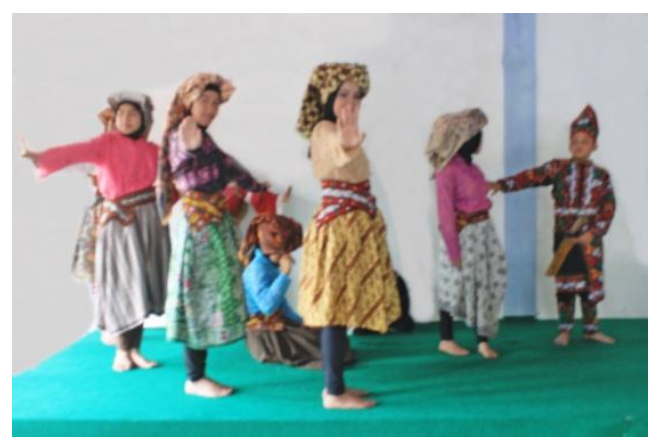


8. Ragam gerak I lapahe (memotong)

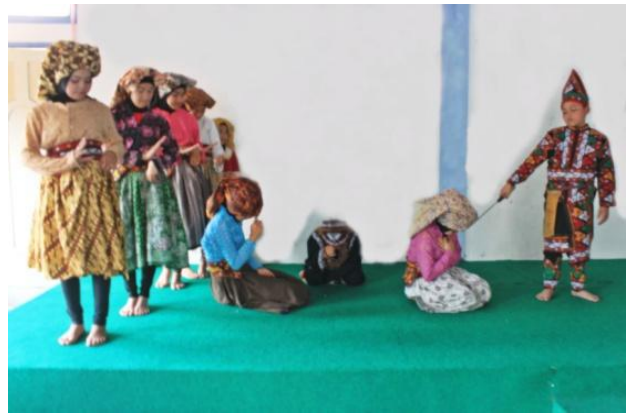

9. Ragam gerak mupancur rayoh

(bercucuran darah)

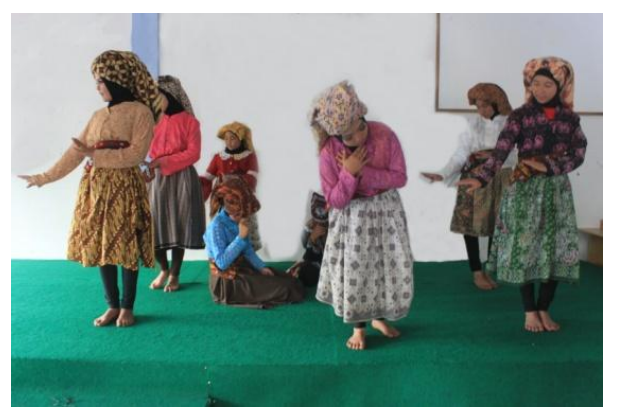

10. Ragam gerak Gunah (sedih)

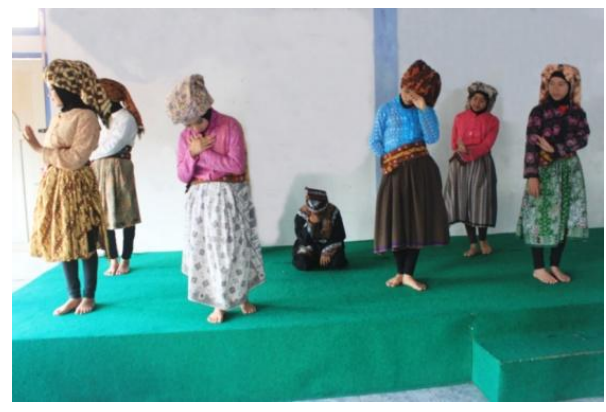

11. Ragam gerak Mongot sebuku (menangis)

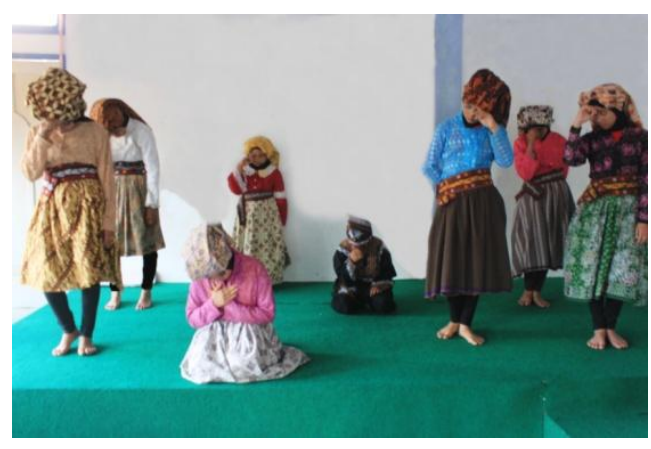

12. Ragam gerak Nunung jematue (mengikuti orang tua)

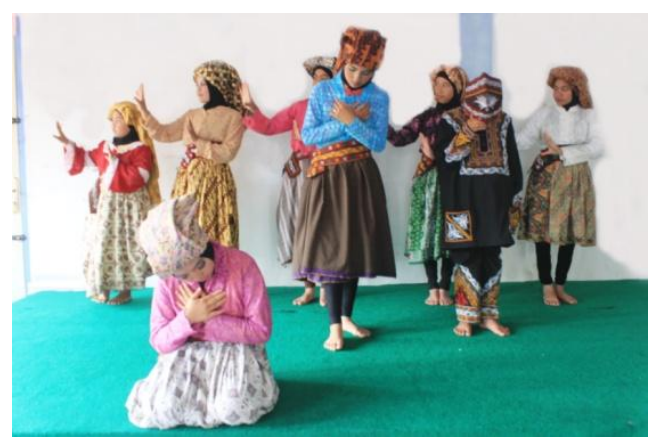

13. Ragam gerak Beloh musangka (pergi berlari) 


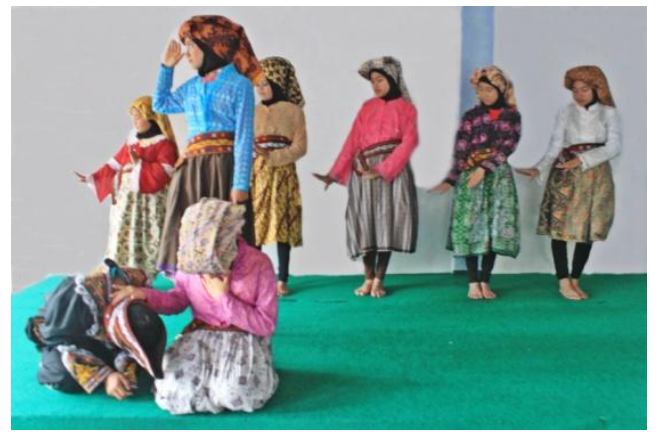

14. Ragam gerak tedoh wet weh (berhenti mengambil air)

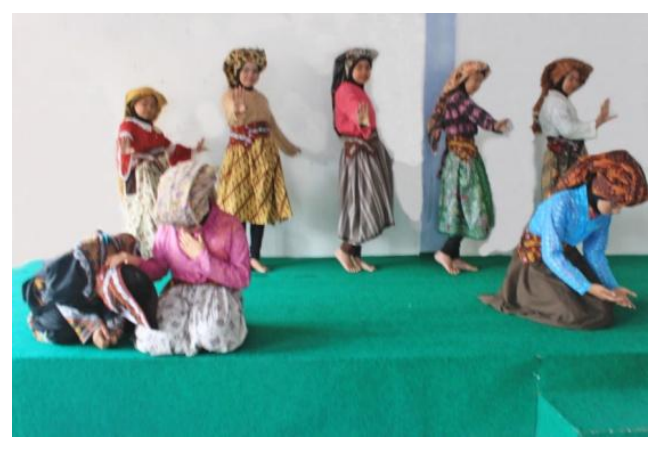

15. Ragam gerak Beloh nyerah nyawa (pergi menyerahkan nyawa)

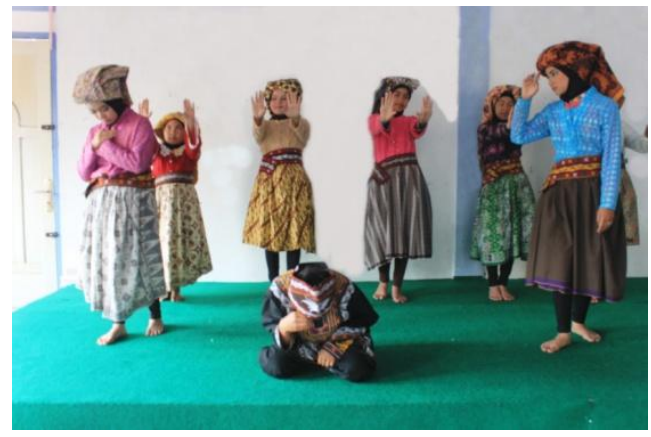

16. Ragam gerak Gelisah

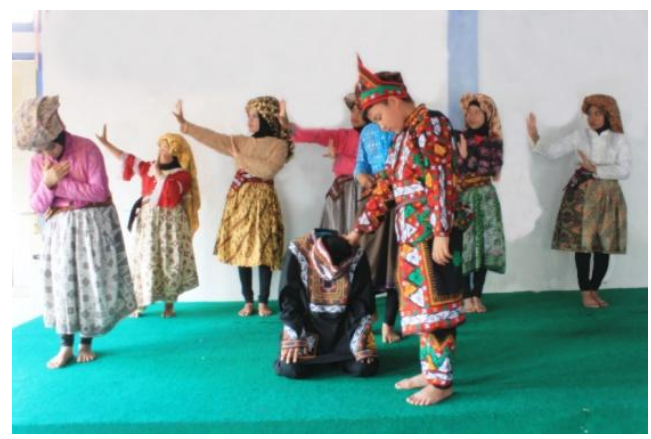

17. Ragam gerak mujadi atu (menjadi batu)

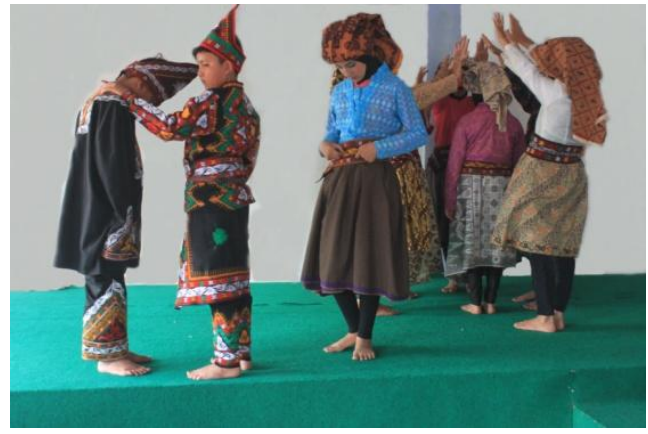

18. Ragam gerak penutup

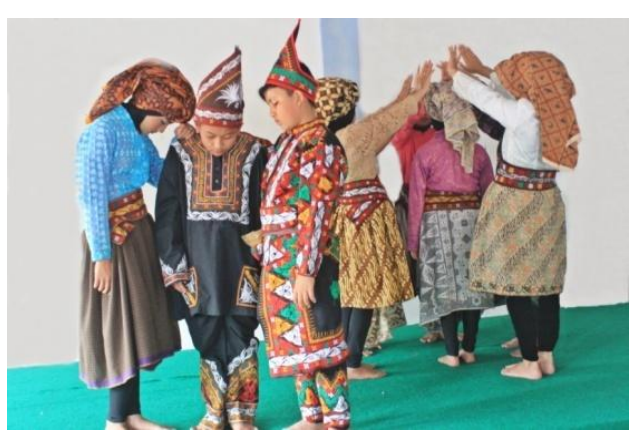




\section{PENUTUP}

\section{Kesimpulan}

Dari hasil penelitian yang dilakukan dilapangan dan penjelasan yang sudah diuraikan mulai dari latar belakang hingga pembahasan, maka dapat disimpulkan secara keseluruhan terhadap tari Atu Belah Pada Masyarakat Gayo Aceh Tengah sebagai berikut :

1. Masyarakat Gayo memiliki beberapa jenis berkesenian lain, seperti sastra lisan yang terbagi kedalam kekeberen ( donggeng), melengkan (kiasan/pantun), pepongoten/sebuku

(tangisan/ratapan), saer (syair), kekitiken (teka-teki), dan peribahasa. Kekeberen adalah seni sastra lisan yang disampaikan oleh orang yang lebih tua kepada yang lebih muda misalnya nenek kepada cucunya, ibu kepada anaknya, bibik kepada untilnya (keponakannya) dan lain-lain yang berisi pesan-pesan moral serta nasihat-nasihat. Kekeberen yang terdapat pada masyarakat Gayo adalah Atu Belah. Dari kisah Atu Belah inilah menginspirasi seorang seniman Ibrahim Kadir menciptakan sebuah kesenian baru yaitu tari Atu Belah.

2. Tari Atu Belah merupakan salah satu tari kreasi dari masyarakat Gayo. Atu Belah berarti batu yang terbuka seperti terbelah dua, tari Atu Belah menggambarkan kesedihan seorang istri yang dimarahi suaminya akibat kelalaiannya menutup lumbung belalang dan akhirnya istrinya masuk kedalam Batu untuk mengakhiri hidupnya. Tari Atu Belah diciptakan pada tahun 1956-an, tari Atu Belah ini ditarikan oleh sembilan seorang penari, dua orang laki-laki dan tujuh penari perempuan.

3. Bentuk penyajian pada tari ini terdiri dari beberapa elemen yaitu gerak, musik 
iringan, properti, tata

busana, dan tata rias, pola

lantai dan pentas. Pada

setiap tahapan dalam tarian

ini diiringi dengan alat

musik dan syair sebagai

pembawa suasana tarian

tersebut. Syair pada tarian

ini juga selaras dengan

gerak yang ditarikan dengan

kata lain syair dapat

memberikan pemahaman

terhadap gerak yang

ditariakan.

\section{A. SARAN}

Dari hasil kesimpulan penelitian diatas, maka dapat diatas, maka dapat dijadikan beberapa saran antara lain sebagai berikut :

1. Penulis berharap dengan adanya penelitian ini masyarakat Gayo untuk menjaga, mengembangkan serta melestarian tari-tarian yang berada pada masyarakat Gayo khususnya di Kabupaten Aceh Tengah.

2. Diharapkan kepada masyarakat Gayo khususnya kepada pemerintah daerah agar senantiasa memperkenalkan berbagai

tari-tarian kepada

masyarakat luas baik lokal maupun diluar daerah. Dengan begitu keberadaan tari-tarian tersebut.

3. Dengan meningkatkan kepedulian terhadap kesenian daerah, berarti telah menyelamatkan anak cucu kita pengaruh budaya luar yang akan merusak budaya sendiri.

4. Memperkenalkan warisan budaya kepada masyarakat luas adalah salah satu wujud cara menghargai dan juga salah satu wujud kecintaan kita terhadap budaya budaya daerah kita sendiri. 


\section{Daftar pustaka}

Arikunto, Suharsimi, 1992. Prosedur Penelitian, Jakarta : Rineke Cipta

Bintang, Murni, Magfirah, 2014. Tari Tuah Kukur Pada Masyarakat Gayo Kabupaten Aceh Tengah Tinjauan, Terhadap Bentuk. Skripsi Sendratasik. Medan : Universitas Negeri Medan.

Desiana, Wahyu, 2014. Tari Kesume Gayo Pada Masyarakat Gayo Kabupaten Aceh Tengah Tinjauan Terhadap Bentuk, Skipsi Sendratasik. Medan : Universitas Negeri Medan.

Fitri, magfirah, 2015. Bentuk Penyajian Tari Inen Mayak Pukes Pada Masyarakat Gayo Aceh Tengah, Skripsi Sendratasik. Medan : Universitas Negeri Medan.

Hermin, Kusmayati. 1989. Makna Tari dalam Upacara di Indonesia. Pidato

Hatta, Hassan, 1996. Gayo Masyarakat dan Kebudayaannya, Jakarta : Balai Pustaka.

Insani, Nurul, 2013. Sejarah dan Bentuk Penyajian Tari Resam Berume pada Masyarakat Gayo di Aceh Tengah, Skripsi Sendratasik. Medan : Universitas Negeri Medan.
Ibrahim, Mahmud. 2002. Syariat dan adat istiadatbjilid I. Takengon : yayasan Maqamah Takengon.

Ibrahim, Mahmud. 2003. Syariat dan adat istiadat jilid II. Takengon : yayasan Maqamah Takengon.

Ibrahim, Mahmud, 2007. Syariat dan adat istiadat jilid III. Takengon : yayasan Maqamah Takengon.

Jazuli, 1994. Sosiologi Tari edisi 1, Yogyakarta, Graha Ilmu

Koentjraningrat, 2004, Kebudayaan, Mentalitas dan Pembangunan, Jakarta : Gramedia Pustaka Utama.

Langer, Suzane K, 1998. Problematika Seni Tari, Terjemah F.X Widaryanto, Bandung : Akademik Seni Tari Indonesia.

Nasir, Muhammad, 1999. Metode Penelitian, Jakarta : Erlangga.

Ruszani, 2006. Tari Oteh Roda Pada Masyarakat Gayo Takengon Kabupaten Aceh Tengah, Skripsi Sendratasik Medan : Universitas Negeri Medan

Soedarsono, 1972, Tari-Tari Indonesia I, Jakarta : Direktorat Jendral 
Kebudayaan Departemen

Pendidikan Kebudayaan.

Soekanto, Soerjono, 1990. Sosiologi, Suatu Pengantar. Jakarta :

PT. Raja Grafindo Persada.

Soedarsono, 1972, Djawa dan Bali :

Dua Pusat Perkembangan

Dramatari tradisional

Indonesia, Yogyakarta :

Gajah Mada. 